\title{
Al-Madãris
}

VOL. 1, NO. 12020

E-ISSN: 2745-9950

https://journal.staijamitar.ac.id/index.php/almadaris

\section{PENERAPAN MODEL PEMBELAJARAN STUDENT TEAMS ACHIEVEMENT DIVISION (STAD) UNTUK MENINGKATKAN HASIL BELAJAR SISWA PADA MATERI GERAK BENDA DI MTSN 3 ACEH UTARA TAHUN AJARAN 2019/2020}

\author{
Ruhul Masyithah \\ MTs.N 3 Aceh Utara \\ Ruhama21@gmail.com
}

\begin{abstract}
The research aims to determine an increase in student learning outcomes and to describe the activities of teachers and students in the application of the STAD (Student Teams Achievement Division) cooperative learning model on straight motion material in MTSN 3 Aceh Utara Academic Year 2019/2020, 2. To describe student responses to application of the STAD (Student Teams Achievement Division) cooperative learning model on straight motion material in MTs.N 3 of North Aceh for the 2019/2020 academic year. This research with a qualitative approach. Thus the sample of this study amounted to 24 people. Data was collected by means of ptk stages. Based on the results of research data analysis. Student learning outcomes using the STAD cooperative learning model increased through the average acquisition of 56.45 in the first cycle, an increase of 8.33 then 63.96 in the second cycle. 2. The activities of teachers and students have increased in the teaching and learning process using the cooperative learning model type Student Teams Achievement Division (STAD), in science subjects on object motion material for class VIII MTsN 3 Aceh Utara students, shown well in cycle 1 teacher activity with good category. There was an increase in cycle 2, namely in the good category. Furthermore, student activity in cycle 1 was categorized as good. and there was an increase in cycle 2 in the very good category.
\end{abstract}

Keywords: Learning model, Student Teams Achievement Division

$\overline{\text { Al-Madaris, Volume l (1), } 2020}$ 


\section{A. Pendahuluan}

Pendidikan merupakan sebuah proses belajar yang dilakukan oleh manusia sepanjang hayat. Belajar adalah kunci utama dari pendidikan. Pendidikan ini penting bagi manusia untuk menghadapi perkembangan jaman yang semakin kompetitif. Pendidikan akan membentuk sumber daya manusia yang berkualitas, sehingga manusia memperoleh bekal untuk bertahan dalam jaman yang semakin berkembang.

Tidak bisa di pungkiri setiap guru mengalami kesulitan dalam menangani peserta didik selama pembelajaran, begitu juga yang dialami penulis. Ketika melakukan pembelajaran IPA, ternyata guru mengalami beberapa masalah yang sangat berpengaruh pada keberhasilan siswa dalam memahami materi ini. Selama pelajaran berlangsung peserta didik terkesan tidak memperhatikan pelajaran, bahkan ada beberapa peserta didik yang bermain-main sendiri, memperhatikan suasana di luar kelas, melamun, atau mengantuk, pada saat guru menyampaikan pertanyaan, peserta didik tidak merespon dengan jawaban yang diharapkan guru. Hal ini berpengaruh pada hasil akhir pembelajaran masih banyak siswa yang belum tuntas KKM nya.

Berdasarkan hasil observasi peneliti di MTsN 3 Aceh Utara pada tanggal 6 Juni 2019, ditemukan bahwa proses pembelajaran masih berpusat pada guru. Selain itu guru masih jarang menggunakan model-model pembelajaran inovatif yang dapat meningkatkan aktivitas pembelajaran yang berpusat pada siswa. Kegiatan belajar mengajar selama ini cenderung menoton dimana siswa lebih banyak menulis, mendengarkan, mencatat dan mengerjakan soal latihan yang diberikan oleh guru. Respon siswa terhadap materi-materi yang diajarkan pun tidak menunjukkan motovasi untuk dipelajari lebih lanjut.

Permasalahan tersebut dipertegas dengan hasil wawancara dengan guru wali kelas VIII di MTsN 3 Aceh Utara, ditemukan bahwa proses belajar mengajar di MTsN 3 Aceh Utara masih jarang menggunakan model-model pembelajaran kooperatif, seperti model pembelajaran STAD, proses belajar cenderung pada teacher centered sehingga guru berceramah menjelaskan materi dan siswa mendengarkan dengan seksama apa yang guru jelaskan. Dengan menggunakan metode seperti itu siswa merasa bosan dan jenuh sehingga membuat mereka justru sibuk dengan kegiatan mereka sendiri.

Salah satu model pembelajaran yang berkembang saat ini adalah pembelajaran kooperatif (cooperative learning), dimana pemebelajaran ini menggunakan kelompok-kelompok kecil sehingga siswa saling berinteraksi dan berkerja sama untuk mecapai suatu tujuan dari pembelajaran. Siswa dalam kelompok kooperatif belajar berdiskusi, saling membantu, dan mengajak satu sama lain untuk mengatasi masalah belajar. Untuk meningkatkan hasil belajar dan keaktifan siswa peneliti mencoba untuk menerapkan metode pembelajaran yang diharapkan mampu meningkatkan hasil belajar dan keaktifan siswa. Yaitu dengan model pembelajaran STAD (Student Teams Achievement Division).

STAD (Metodepembelajaran Student Teams Achievement Division) merupakan salah satu tipe dari model pembelajaran kooperatif yang paling sederhana dan mudah digunakan bagi guru yang ingin memulai pembelajaran dengan model kooperatif di kelas. Melalui Model Pembelajaran kooperatif model STAD ini

$\overline{\text { Al-Madãris, Volume l (1), } 2020}$ 
diharapkan dapat menciptakan pembelajaran yang kondusif dan memudahkan peserta didik untuk fokus dalam memahami pelajaran yang disampaikan oleh guru.

\section{B. Review Literatur}

Model pembelajaran STAD (Student Teams Achievement Divisions) merupakan salah satu metode pembelajaran kooperatif yang paling sederhana, dan merupakan odel yang paling baik untuk permulaan bagi para guru yang baru menggunakan pendekatan kooperatif (Slavin 2009:142). STAD terdiri atas lima komponen utama presentasi kelas, tim, kuis, skor, kemajuan individual, rekognisi tim (Slavin 2009:142).

1. Presentasi Kelas (penyajian materi)

Materi dalam STAD pertama-tama diperkenalkan di dalam kelas. Ini merupakan pengajaran langsung seperti yang sering kali dilakukan atau didiskusi pelajaran yang dipimpin oleh guru, tetapi bisa juga memasukan presentasi audio visual. Bedanya presentasi kelas dengan pengajaran biasa hanyalah bahwa presentasi tersebut haruslah benarbenarberfokus pada unit STAD. Dengan cara ini, para siswa akan menyadari bahwa meraka harus benar-benar memberi perhatian penuh selama presentasi kelas, karena dengan demikian akan sangat membantu mereka mengerjakan kuis-kuis, dan skor kuis mereka menentukan skor tim mereka.

\section{Tim (Kerja kelompok)}

Tim terdiri dari empat atau lima siswa yang mewakili seluruh bagian dari kelas dalam hal kinerja akademik, jenis kelamin, ras, dan etnisitas. Fungsi utama dari tim ini adalah memastikan bahwa semua anggota tim benar-benar belajar, dan lebih khususnya lagi, adalah untuk mempersiapkan anggotanya untuk bisa mengerjakan kuis dengan baik. Setelah guru menyampaikan materinya, tim berkumpul untuk mempelajari lembar kegiatan atau materi lainnya. Yang paling sering terjadi, pembelajaran itu melibatkan pembahasan permasalahan bersama, membandingkan jawaban, dan mengoreksi tiap kesalahan pemahaman apabila anggota tim yang membuat kesalahan.

3. Kuis

Setelah sekitar satu atau dua periode setelah guru memberikan presentasi dan sekitar satu atau dua periode praktik tim. para siswa akan mengerjakan kuis individual. Para siswa tidak diperbolehkan untuk saling membantu dalam mengerjakan kuis. Sehingga, tiap siswa bertanggung jawab secara individual untuk memahami materinya.

4. Skor Kemajuan Individual (penghargaan individu)

Gagasan dibalik skor kemajuan induvidual adalah untuk memberikan kepada tiap siswa tujuan kinerja yang akan dapat dicapai apabia mereka bekerja lebih giat dan memberikan kinerja yang lebih baik daripada sebelumnya. Tiap siswa dapat memberikan kontribusi poin yang maksimal kepada timnya dalam sistem skor ini, tetapi tidak ada siswa yang dapat melakukannya tanpa memberikan usaha mereka yang terbaik. Tiap siswa diberikan skor "awal", yang diperoleh dari ratarata kinerja siswa tersebut sebelumnnya dalam mengerjakan kuis yang sama. Siswa selanjutnya akan mengumpulan point untuk tim mereka 
berdasarkan tingkat kenaikan skor kuis mereka dibandingkan dengan skor awal mereka.

5. Rekognisi tim (Penghargaan Kelompok)

Tim akan mendapatkan sertifikat atau bentuk penghargaan yang lain apabila skor rata-rata mereka mencapai kriteria tertentu. Skor tim siswa dapat juga digunakan untuk menentukan dua puluh persen dari peringkat mereka. Penghargaan ini diberikan kepada 3 kelompok terbaik yaitu: 1) kelompok baik, 2) kelompok hebat, 3) kelompok super.

Hasil belajar merupakan bukti bahwa seseorang telah belajar ialah terjadinya perubahan tingkah laku pada orang tersebut, misalnya dari tidak tahu menjadi tahu, dan dari tidak mengerti menjadi mengerti. Hasil belajar merupakan perubahan yang terjadi pada individu yang belajar, bukan saja perubahan mengenai perubahan tetapi juga pembentuka kecakapan, sikap, pengertian, penguasaan, dan penghargaan dalam diri individu yang belajar

Hasil belajar siswa tentunya dipengaruhi oleh beberapa faktor yang saling berkaitan salah satunya adalah faktor yang datang dari dalam diri siswa terutama kemampuan yang dimilikinya. Faktor kemampuan siswa besar sekali pengaruhnya terhadap hasil belajar yang dicapai. Hal ini juga sesuai seperti yang dikemukakan Clark (Sudjana, 2011: 39) "Bahwa hasil belajar siswa di sekolah 70\% dipengaruhi oleh kemampuan siswa dan 30\% dipengaruhi oleh lingkungan”. Disamping faktor kemampuan yang dimiliki siswa, juga ada faktor lain, seperti motivasi belajar, minat, perhatian, sikap, kebiasaan belajar, ketekunan, sosial ekonomi, faktor fisik dan psikis. Sedangkan faktor lingkungan salah satunya lingkungan belajar yang paling dominan mempengaruhi hasil belajar siswa di sekolah adalah kualitas pengajaran.

\section{Metodelogi}

Penelitian ini menggunakan pendekatan dalam penelitian ini menggunakan pendekatan kualitatif. Pendekatan kualitatif adalah suatu proses penelitian dan pemahaman yang berdasarkan pada metodelogi yang menyelidiki suatu fenomena social dan masalah manusia, penelitian kualitatif dilakukan pada kondisi alamiah dan bersifat penemuan.

Berdasarkan permasalahan yang diajukan dalam penelitian yang lebih mengutamakan pada peningkatan hasil belajar siswa, aktifitas guru dalam pembelajaran, dan respon siswa terhadap penerapan model pembelajaran kooperatif tipe STAD, maka jenis penelitian ini termasuk Penelitian Tindakan Kelas (PTK) Karena peneliti terlibat langsung dari awal pembelajaran hingga akhir pembelajaran pada materi gerak benda

Jadi menurut peneliti, penelitian tidakan kelas adalah salah satu upaya guru dalam bentuk berbagai kegiatan yang dilakukan untuk memperbaiki dan meningkatkan mutu pembelajaran dikelas. 


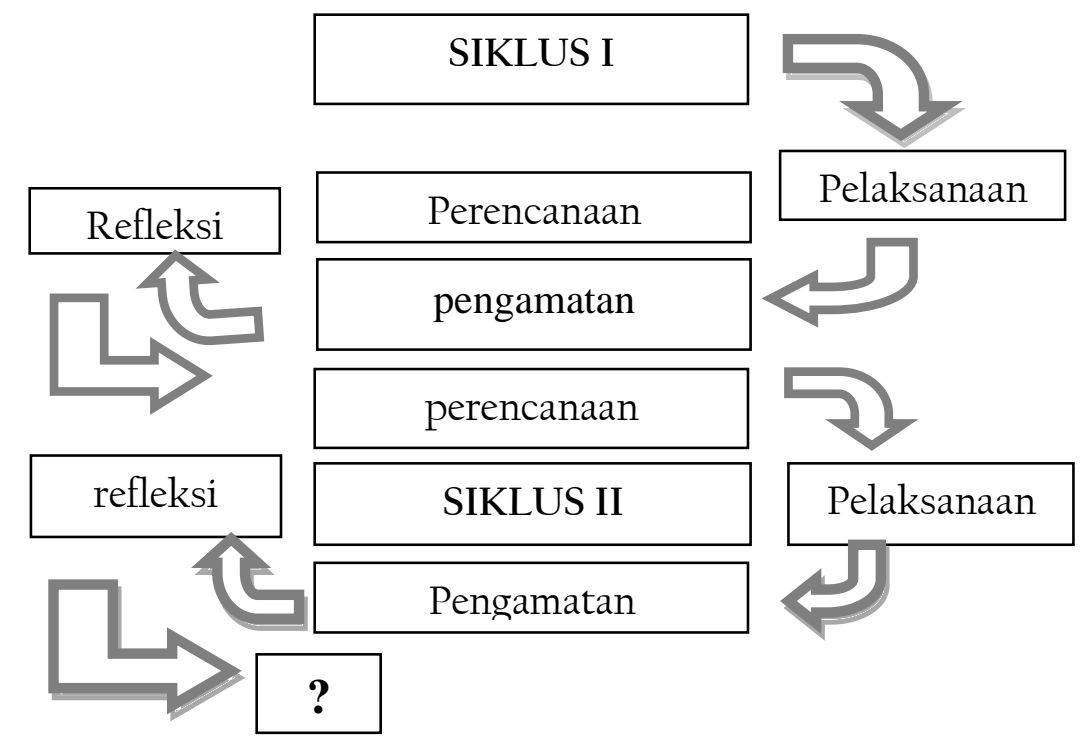

Secara umum penelitian ini dilakukan dalam dua siklus, dimana setiap siklus terdapat 4 tahapan. Menurut Arikunto (2013:137) "Tahap-tahapnya adalah:

1. Perencanaan

Pada tahap perencanaan dilakukan berbagai persiapan dan perencanaan terdiri dari:

a). Menyusun rencana pelaksanaan pembelajaran (RPP) dan materi sistem rem yang akan digunakan dalam pembelajaran dengan model pembelajaran kooperatif tipe Student Teams Achievement Division (STAD)

b). Menyusun soal test.

c). Menyusun lembar kerja peserta didik (LKPD).

d). Menyusun lembar aktivitas guru dan siswa.

e). Menyusun angket respon siswa.

2. Pelaksanaan Tindakan

Pelaksanaan tindakan dalam penelitian ini yaitu peneliti melaksanakan pembelajaran menggunakan Model pembelajaran kooperatif Student Teams Achievement Division (STAD) berdasarkan instrumen perangkat pembelajaran yang telah disusun.

3. Pengamatan atau Observasi

Selama peneliti melakukan proses pembelajaran dengan menggunakan model pembelajaran kooperatif tipe STAD. Peneliti dibantu oleh dua oang pengamat yang teridiri dari guru dan teman sejawat. Pengamatan dilakukan dengan menggunakan lembar aktivitas guru dan siswa untuk mengetahui tingkat keterampilan dan efektivitas. Penerapan model pembelajaran kooperatif tipe STAD pada materi sistem gerak lurus.

4. Refleksi

Setelah semua data terkumpul dan dianalisis baik aktivitas guru, aktivitas siswa, dan tes kinerja siswa kemudian dilakukan indentifikasi permasalahan yang muncul dalam pelakasanaan proses pembelajaran, dari permasalahan yang muncul dicari pemecahannya dan menemukan langkah-langkah yang tepat untuk mengatasi masalah tersebut, sehingga pada saat pelaksanaan 
siklus selanjutnya tidak ada permasalahan yang muncul lagi, seperti permasalahan yang muncul pada siklus pertama I.

\section{Hasil Penelitian}

\section{Hasil siklus I dan siklus II}

\section{a. Perencanaan Tindakan}

Sebelum melakukan penelitian tindakan kelas, peneliti melakukan perencanaan agar kegiatan pembelajaran yang berlangsung dapat berjalan secara efektif. Perencanaan yang dilakukan oleh peneliti adalah sebagai berikut: 1.Menyusun Rencana Pelaksanaan Pembelajaran (RPP), 2. Menyiapkan materi pembelajaran.

\section{b. Pelaksanaan/Tindakan}

Pelaksanaan/tindakan siklus I dan siklus II dilakukan pada tanggal 23 Juli 2019 sampai tanggal 20 Agustus 2019. Jumlah subjek penelitian sebanyak 24 siswa yang ada pada kelas VIII MTsN Aceh Utara. Sementara itu, peneliti bertindak sebagai guru yang menerapkan model pembelajaran tipe Student Teams Achievement Division (STAD) pada mata pelajaran IPA. Adapun kegiatan yang dilakukan terdiri dari kegiatan awal, inti, dan penutup.

\section{c. Pengamatan/observasi}

Hasil observasi aktivitas guru selama proses tindakan siklus I dan siklus II berlangsung dalam pembelajaran IPA model pembelajaran tipe Student Teams Achievement Division (STAD) dapat dilihat pada tabel 4.1 berikut :

Tabel 4.1

Hasil Observasi Aktivitas Guru Pada Siklus I.

\begin{tabular}{|c|c|c|c|c|c|c|c|}
\hline \multirow{2}{*}{ NO } & \multirow{2}{*}{ Aspek/Indikator Yang Diamati } & \multicolumn{2}{|c|}{ Aktivitas } & \multicolumn{4}{|c|}{ Nilai } \\
\hline & & $\mathrm{Ya}$ & Tidak & 1 & 2 & 3 & 4 \\
\hline 1. & $\begin{array}{l}\text { Guru memberikan soal pretest } \\
\text { kepeada siswa sebelum memulai } \\
\text { materi pembelajaran. }\end{array}$ & $\sqrt{ }$ & & & & & $\checkmark$ \\
\hline 2. & $\begin{array}{l}\text { Guru menyebutkan tujuan } \\
\text { pembelajaran menggunakan model } \\
\text { STAD. }\end{array}$ & $\sqrt{ }$ & & & & & \\
\hline 3. & $\begin{array}{l}\text { Guru menjelaskan materi } \\
\text { pembelajaran. }\end{array}$ & $\sqrt{ }$ & & & & & \\
\hline 4. & $\begin{array}{l}\text { Guru membagi siswa menjadi } \\
\text { beberapa kelompok secara heterogen } \\
(3-5 \text { siswa). }\end{array}$ & $\sqrt{ }$ & & & & & 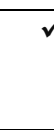 \\
\hline 5. & $\begin{array}{l}\text { Guru membagikan tugas pada tiap } \\
\text { kelompok dengan menggunakan LKS. }\end{array}$ & $\sqrt{ }$ & & & & & \\
\hline 6. & $\begin{array}{l}\text { Guru berkeliling memantau siswa } \\
\text { berdiskusi dalam masing-masing } \\
\text { kelompok. }\end{array}$ & $\checkmark$ & & & & & \\
\hline 7. & $\begin{array}{l}\text { Guru memfasilitasi masing-masing } \\
\text { tiap kelompok untuk } \\
\text { mempresentasikan hasil kerja } \\
\text { kelompok. }\end{array}$ & $\checkmark$ & & & & & \\
\hline 8. & $\begin{array}{l}\text { Guru memberikan kesempatan } \\
\text { bertanya kepada kelompok lain }\end{array}$ & $\sqrt{ }$ & & & & & \\
\hline
\end{tabular}

Al-Madãris, Volume 1 (1), 2020 


\begin{tabular}{|c|c|c|c|}
\hline & $\begin{array}{l}\text { terhadap kelompok yang sudah } \\
\text { melakukan presentasi. }\end{array}$ & & \\
\hline 9. & $\begin{array}{l}\text { Guru memberikan kuis secara } \\
\text { individual }\end{array}$ & $\checkmark$ & $\checkmark$ \\
\hline 10. & $\begin{array}{l}\text { Guru memberikan penghargaan } \\
\text { kepada invidu dengan nilai paling } \\
\text { bagus. }\end{array}$ & $\checkmark$ & $\checkmark$ \\
\hline 11. & $\begin{array}{l}\text { Guru memberikan penghargaan } \\
\text { kepada kelompok dengan nilai paling } \\
\text { bagus. }\end{array}$ & $\checkmark$ & $\sqrt{ }$ \\
\hline 12. & $\begin{array}{l}\text { Guru meminta perwakilan siswa } \\
\text { untuk menyimpulkan materi. }\end{array}$ & $\checkmark$ & $\checkmark$ \\
\hline 13. & Guru membagikan soal posttest & $\checkmark$ & $\checkmark$ \\
\hline
\end{tabular}

\begin{tabular}{cc}
\hline Jumlah skor & 44 \\
\hline Rata-rata & 3,38 \\
\hline Kategori & Baik \\
\hline
\end{tabular}

Berdasarkan tabel di atas maka dapat disimpulkan bahwa aktivitas guru dalam pembelajaran perawatan sasis sepeda motor materi sistem gerak benda menggunakan model pembelajaran kooperatif tipe STAD termasuk katagori baik $(3,38)$.

Tabel 4.2

Hasil Observasi Aktivitas Guru pada Siklus II.

\begin{tabular}{|c|c|c|c|c|c|c|c|}
\hline \multirow{2}{*}{ NO } & \multirow{2}{*}{ Aspek/Indikator Yang Diamati } & \multicolumn{2}{|c|}{ Aktivitas } & \multicolumn{4}{|c|}{ Nilai } \\
\hline & & $\mathrm{Ya}$ & Tidak & 1 & 2 & 3 & 4 \\
\hline 1. & $\begin{array}{l}\text { Guru memberikan soal pretest } \\
\text { kepeada siswa sebelum memulai } \\
\text { materi pembelajaran. }\end{array}$ & $\checkmark$ & & & & & $\checkmark$ \\
\hline 2. & $\begin{array}{l}\text { Guru menyebutkan tujuan } \\
\text { pembelajaran menggunakan model } \\
\text { STAD. }\end{array}$ & $\checkmark$ & & & & & $\checkmark$ \\
\hline 3. & $\begin{array}{l}\text { Guru menjelaskan materi } \\
\text { pembelajaran. }\end{array}$ & $\checkmark$ & & & & & $\checkmark$ \\
\hline 4. & $\begin{array}{l}\text { Guru membagi siswa menjadi } \\
\text { beberapa kelompok secara heterogen } \\
(3-5 \text { siswa). }\end{array}$ & $\bar{v}$ & & & & & $\checkmark$ \\
\hline 5. & $\begin{array}{l}\text { Guru membagikan tugas pada tiap } \\
\text { kelompok dengan menggunakan } \\
\text { LKPD. }\end{array}$ & $\checkmark$ & & & & & $\checkmark$ \\
\hline 6. & $\begin{array}{l}\text { Guru berkeliling memantau siswa } \\
\text { berdiskusi dalam masing-masing } \\
\text { kelompok. }\end{array}$ & $\checkmark$ & & & & & $\checkmark$ \\
\hline 7. & $\begin{array}{l}\text { Guru memfasilitasi masing-masing } \\
\text { tiap kelompok untuk } \\
\text { mempresentasikan hasil kerja } \\
\text { kelompok. }\end{array}$ & $\checkmark$ & & & & & \\
\hline 8. & $\begin{array}{l}\text { Guru memberikan kesempatan } \\
\text { bertanya kepada kelompok lain } \\
\text { terhadap kelompok yang sudah } \\
\text { melakukan presentasi. }\end{array}$ & $\checkmark$ & & & & & $\checkmark$ \\
\hline
\end{tabular}




\begin{tabular}{|c|c|c|c|}
\hline 9. & $\begin{array}{l}\text { Guru memberikan kuis secara } \\
\text { individual }\end{array}$ & $\checkmark$ & $\checkmark$ \\
\hline 10. & $\begin{array}{l}\text { Guru memberikan penghargaan } \\
\text { kepada invidu dengan nilai paling } \\
\text { bagus. }\end{array}$ & $\checkmark$ & $\checkmark$ \\
\hline 11. & $\begin{array}{l}\text { Guru memberikan penghargaan } \\
\text { kepada kelompok dengan nilai paling } \\
\text { bagus. }\end{array}$ & $\checkmark$ & $\checkmark$ \\
\hline 12. & $\begin{array}{l}\text { Guru meminta perwakilan siswa } \\
\text { untuk menyimpulkan materi. }\end{array}$ & $\checkmark$ & $\checkmark$ \\
\hline 13. & Guru membagikan soal posttest & $\checkmark$ & $\checkmark$ \\
\hline & Jumlah skor & 51 & \\
\hline & Rata-rata & 3,92 & \\
\hline & Kategori & Sangat Baik & \\
\hline
\end{tabular}

Hasil pengamatan aktivitas guru pada siklus II di atas menunjukkan bahwa terjadi peningkatan aktivitas guru mengelola proses pembelajaran mata pelajaran perawatan sasis sepeda motor materi gerak benda dari pada siklus sebelumnya, pada siklus ke II kategori pengamatan aktivitas guru menunjukkan bahwa aktivitas guru pada siklus II termasuk kategori sangat baik.

a) Observasi aktivitas siswa

Observasi aktivitas siswa dilakukan mulai dari pelaksanaan tindakan berlangsung sampai akhir proses pelaksanaan tindakan selesai. Pada pertemuan pertama siklus I ini jumlah siswa yang hadir sebanyak 24 siswa. Berikut hasil observasi aktivitas siswa selama proses pembelajaran berlangsung.

Tabel 4.3

Hasil Observasi Aktivitas Siswa Pada Siklus I.

\begin{tabular}{|c|c|c|c|c|c|c|c|}
\hline \multirow{2}{*}{ NO } & \multirow{2}{*}{ Aspek/Indikator Yang Diamati } & \multicolumn{2}{|c|}{ Aktivitas } & \multicolumn{4}{|c|}{ Nilai } \\
\hline & & $\mathrm{Ya}$ & Tidak & 1 & 2 & 3 & 4 \\
\hline 1. & $\begin{array}{l}\text { Siswa mengerjakan soal postest yang } \\
\text { diberikan guru }\end{array}$ & $\checkmark$ & & & & & s \\
\hline 2. & $\begin{array}{l}\text { Siswa mendengarkan, dan } \\
\text { memperhatikan presentasi guru. }\end{array}$ & $\checkmark$ & & & & & \\
\hline 3. & $\begin{array}{l}\text { Siswa mendengarkan materi yang } \\
\text { disampaikan guru. }\end{array}$ & $\checkmark$ & & & & & \\
\hline 4. & $\begin{array}{l}\text { Siswa membentuk kelompok sesuai } \\
\text { dengan yang diberikan oleh guru. }\end{array}$ & $\checkmark$ & & & & & \\
\hline 5. & $\begin{array}{l}\text { Siswa mengerjakan tugas bersama } \\
\text { kelompok yang diberikan guru } \\
\text { meggunakan LKS. }\end{array}$ & $\checkmark$ & & & & & \\
\hline 6. & $\begin{array}{l}\text { Siswa mengamati dan mempelajari } \\
\text { LKS yang dibagikan oleh guru. }\end{array}$ & $\checkmark$ & & & & & \\
\hline 7. & $\begin{array}{l}\text { Siswa bersama kelompoknya masing- } \\
\text { masing mempresentasikan hasil kerja } \\
\text { mereka. }\end{array}$ & $\sqrt{ }$ & & & & & \\
\hline 8. & $\begin{array}{l}\text { Siswa bertanya kepada kepada } \\
\text { kelompok yang sudah } \\
\text { mempresentasikan. }\end{array}$ & $\sqrt{ }$ & & & & & \\
\hline 9. & $\begin{array}{l}\text { Siswa mengerjakan kuis secara } \\
\text { individu. }\end{array}$ & $\sqrt{ }$ & & & & & \\
\hline
\end{tabular}




\begin{tabular}{|c|c|c|c|}
\hline 10. & $\begin{array}{l}\text { Siswa dengan nilai terbaik menerima } \\
\text { penghargaan individu. }\end{array}$ & $\checkmark$ & $\checkmark$ \\
\hline 11. & $\begin{array}{l}\text { Siswa bersama kelompok dengan } \\
\text { nilai terbaik menerima penghargaan } \\
\text { yang diberikan oleh guru. }\end{array}$ & $\sqrt{ }$ & $\checkmark$ \\
\hline 12. & $\begin{array}{l}\text { Siswa menyimpulkan materi yang } \\
\text { sudah dipelajari. }\end{array}$ & $\checkmark$ & $\checkmark$ \\
\hline 13. & $\begin{array}{l}\text { Siswa mengerjakan soal posttest yang } \\
\text { diberikan oleh guru. }\end{array}$ & $\checkmark$ & $\bar{v}$ \\
\hline & Jumlah skor & 42 & \\
\hline & Rata-rata & 3,23 & \\
\hline & Kategori & Baik & \\
\hline
\end{tabular}

Berdasarkan tabel di atas maka dapat disimpulkan bahwa aktivitas siswa dalam pembelajaran IPA materi gerak benda menggunakan model pembelajaran kooperatif tipe STAD termasuk katagori baik $(3,23)$.

\section{Tabel 4.4}

Hasil Observasi Aktivitas Siswa Pada Siklus II.

\begin{tabular}{|c|c|c|c|c|c|c|c|}
\hline \multirow{2}{*}{ NO } & \multirow{2}{*}{ Aspek/Indikator Yang Diamati } & \multicolumn{2}{|c|}{ Aktivitas } & \multicolumn{4}{|c|}{ Nilai } \\
\hline & & $\mathrm{Ya}$ & Tidak & 1 & 2 & 3 & 4 \\
\hline 1. & $\begin{array}{l}\text { Siswa mengerjakan soal pretest yang } \\
\text { diberikan guru }\end{array}$ & $\checkmark$ & & & & & $\checkmark$ \\
\hline 2. & $\begin{array}{l}\text { Siswa mendengarkan, dan } \\
\text { memperhatikan presentasi guru. }\end{array}$ & $\sqrt{ }$ & & & & & $\checkmark$ \\
\hline 3. & $\begin{array}{l}\text { Siswa mendengarkan materi yang } \\
\text { disampaikan guru. }\end{array}$ & $\checkmark$ & & & & & $\checkmark$ \\
\hline 4. & $\begin{array}{l}\text { Siswa membentuk kelompok sesuai } \\
\text { dengan yang diberikan oleh guru. }\end{array}$ & $\sqrt{ }$ & & & & & $\checkmark$ \\
\hline 5. & $\begin{array}{l}\text { Siswa mengerjakan tugas bersama } \\
\text { kelompok yang diberikan guru } \\
\text { meggunakan LKPD. }\end{array}$ & $\sqrt{ }$ & & & & & $\checkmark$ \\
\hline 6. & $\begin{array}{l}\text { Siswa mengamati dan mempelajari } \\
\text { LKPD yang dibagikan oleh guru. }\end{array}$ & $\sqrt{ }$ & & & & & $\sqrt{ }$ \\
\hline 7. & $\begin{array}{l}\text { Siswa bersama kelompoknya } \\
\text { masing-masing mempresentasikan } \\
\text { hasil kerja mereka. }\end{array}$ & $\checkmark$ & & & & & $\checkmark$ \\
\hline 8. & $\begin{array}{l}\text { Siswa bertanya kepada kelompok } \\
\text { yang sudah mempresentasikan. }\end{array}$ & $\sqrt{ }$ & & & & & $\sqrt{ }$ \\
\hline 9. & $\begin{array}{l}\text { Siswa mengerjakan kuis secara } \\
\text { individu. }\end{array}$ & $\checkmark$ & & & & & \\
\hline 10. & $\begin{array}{l}\text { Siswa dengan nilai terbaik menerima } \\
\text { penghargaan individu. }\end{array}$ & $\sqrt{ }$ & & & & & $\checkmark$ \\
\hline 11. & $\begin{array}{l}\text { Siswa bersama kelompok dengan } \\
\text { nilai terbaik menerima penghargaan } \\
\text { yang diberikan oleh guru. }\end{array}$ & $\sqrt{ }$ & & & & & $\checkmark$ \\
\hline 12 . & $\begin{array}{l}\text { Siswa menyimpulkan materi yang } \\
\text { sudah dipelajari. }\end{array}$ & $\sqrt{ }$ & & & & & \\
\hline 13. & $\begin{array}{l}\text { Siswa mengerjakan soal posttest } \\
\text { yang diberikan oleh guru. }\end{array}$ & $\checkmark$ & & & & & $\checkmark$ \\
\hline & Jumlah skor & & & 50 & & & \\
\hline & Rata-rata & & & 3,84 & & & \\
\hline & Kategori & & & ac & & & \\
\hline
\end{tabular}


Hasil pengamatan aktivitas guru pada siklus II di atas menunjukkan bahwa terjadi peningkatan aktivitas guru mengelola proses pembelajaran mata pelajaran IPA dari pada siklus sebelumnya, pada siklus ke I nilai rata-rata 3.38 terjadi peningkatan pada siklus ke II menjadi 3.92. kategori pengamatan aktivitas guru menunjukkan bahwa aktivitas guru pada siklus II termasuk kategori sangat baik.

\section{d. Refleksi}

Untuk mengetahui hasil belajar siswa, diberikan soal post-test pada akhir pelaksanaan pembelajaran. hasil test siswa pada siklus I dan siklus II dapat dilihat pada tabel 4.5 berikut.

Tabel 4.5.

Hasil Peningkatan Nilai Hasil Belajar

\begin{tabular}{|c|c|c|c|c|}
\hline \multirow{2}{*}{ No } & \multirow{2}{*}{ Siswa } & \multicolumn{3}{|c|}{ Peningkatan Nilai Hasil Belajar } \\
\hline & & Siklus I & Meningkat & Siklus II \\
\hline 1 & 2 & 3 & 4 & 5 \\
\hline 1 & $X-1$ & 65 & 5 & 70 \\
\hline 2 & $X-2$ & 60 & 5 & 65 \\
\hline 3 & $X-3$ & 50 & 10 & 60 \\
\hline 4 & $X-4$ & 50 & 10 & 60 \\
\hline 5 & $X-5$ & 40 & 10 & 50 \\
\hline 6 & $\mathrm{X}-6$ & 40 & 20 & 60 \\
\hline 7 & $X-7$ & 70 & - & 70 \\
\hline 8 & $X-8$ & 50 & 5 & 55 \\
\hline 9 & X-9 & 65 & 20 & 80 \\
\hline 10 & $X-10$ & 55 & 5 & 60 \\
\hline 11 & X-11 & 60 & 5 & 65 \\
\hline 12 & $X-12$ & 45 & 25 & 70 \\
\hline 13 & $X-13$ & 55 & 5 & 60 \\
\hline 14 & $X-14$ & 55 & 5 & 60 \\
\hline 15 & $X-15$ & 60 & 10 & 70 \\
\hline 16 & $X-16$ & 55 & 5 & 60 \\
\hline 17 & $X-17$ & 50 & 15 & 65 \\
\hline 18 & $X-18$ & 60 & 5 & 65 \\
\hline 19 & $X-19$ & 60 & 5 & 65 \\
\hline 20 & $X-20$ & 55 & 5 & 60 \\
\hline 21 & $X-21$ & 65 & 5 & 70 \\
\hline 22 & $X-22$ & 60 & - & 55 \\
\hline 23 & $X-23$ & 65 & 5 & 70 \\
\hline
\end{tabular}




\begin{tabular}{lllll}
\hline 24 & $X-24$ & 60 & 15 & 75 \\
\hline Jumlah & 1355 & 200 & 1535 \\
\hline Rata-rata & 56,45 & 8,33 & 63,96 \\
\hline
\end{tabular}

Tabel 4.6.

Distribusi Frekuensi Peningkatan Hasil Belajar

\begin{tabular}{lllll}
\hline Interval & Kriteria & $\begin{array}{l}\text { Siklus I } \\
(f)\end{array}$ & Meningkat & $\begin{array}{l}\text { Siklus II } \\
(f)\end{array}$ \\
\hline 1 & 2 & 3 & 4 & 5 \\
\hline $80-100$ & $\begin{array}{l}\text { Baik } \\
\text { Sekali }\end{array}$ & 0 & 1 & 1 \\
\hline $66-79$ & Baik & 1 & 6 & 7 \\
\hline $56-65$ & Cukup & 11 & 2 & 13 \\
\hline $40-55$ & Kurang & 10 & - & 3 \\
\hline $30-39$ & Gagal & 0 & - & - \\
\hline
\end{tabular}

Dari Tabel 4.6 di atas dapat diketahui bahwa perolehan nilai siswa pada siklus I dan siklus II mengalami peningkatan sesuai dengan hasil belajar. Adapun untuk mengetahui persentase peningkatan hasil belajar siswa dari hasil tes sikus I ke siklus II, maka persentase hasil belajar ditabulasikan seperti terlihat dalam Tabel 4.7.

Tabel 4.7.

Distribusi Frekuensi Persentase Hasil Belajar Siswa

\begin{tabular}{ccccc}
\hline Interval & Kriteria & $\begin{array}{c}\text { Siklus I } \\
(\%)\end{array}$ & Meningkat & $\begin{array}{c}\text { Siklus II } \\
(\%)\end{array}$ \\
\hline 1 & 2 & 3 & 4 & 5 \\
\hline $80-100$ & $\begin{array}{c}\text { Baik } \\
\text { Sekali }\end{array}$ & 0,00 & 4,17 & 4,17 \\
\hline $66-79$ & Baik & 4,17 & 25,0 & 29,2 \\
\hline $56-65$ & Cukup & 45,8 & 8,40 & 54,2 \\
\hline $40-55$ & Kurang & 41,7 & - & 12,5 \\
\hline $30-39$ & Gagal & 0,00 & - & - \\
\hline
\end{tabular}

Respon siswa dilakukan dengan mengedarkan angket, maka hasil penelitian dan pengolahan data melalui angket diperoleh gambaran mengenai respon siswa, adapun perolehan nilai tertinggi $94,21 \%$ yaitu terdapat pada tanggapan siswa merasa terbantu dengan adanya model pembelajaran kooperatif tipe STAD dalam mengatasi kesulitan belajar. Adapun persentase nilai terendah 39,93\% yaitu terdapat pada tanggapan siswa agar model pembelajaran kooperatif tipe STAD digunakan dalam pembelajaran materi gerak benda selanjutnya dan mata pelajaran lain. 


\section{E. Pembahasan}

Penelitian tindakan kelas ini terdiri dari 2 siklus, setiap siklus terdiri dari 1 pertemuan. Dalam kegiatan penelitian ini dibagi menjadi 3 kegiatan utama, yaitu kegiatan awal, kegiatan inti, dan kegiatan akhir pada pertemuan pertama. Kegiatan awal yang dilakukan yakni peneliti melakukan aktivitas meliputi: mengucap salam, berdoa, mengecek kehadiran siswa dan menyampaikan tujuan pembelajaran. Peneliti memotivasi dan membagi kelompok. Hal ini bertujuan agar siswa lebih tertarik dan bersemangat dalam mengikuti pembelajaran. Pada kegiatan inti, peneliti menyampaikan materi kepada siswa atau kegiatan presentasi guru, selanjutnya kegiatan belajar dalam tim dimana siswa dapat belajar dengan teman satu timnya, dan diteruskan kegiatan evaluasi, dan kegiatan penghargaan tim. Pada kegiatan akhir, peneliti memberikan pertanyaan lisan secara acak kepada siswa untuk mengecek pemahaman siswa terhadap materi yang sudah diberikan, peneliti juga mengajak siswa untuk menyimpulkan materi yang telah diberikan pada hari itu. Kemudian peneliti menutup pembelajaran dengan membaca doa.

Aktivitas guru dalam penelitian ini merupakan kegiatan yang dilakukan guru selama pembelajaran perawatan sasis sepeda motor materi sistem rem menggunakan model tipe Student Teams Achievement Division (STAD) yang diukur melalui lembar observasi yang telah dipersiapkan. Hasil observasi menunjukkan peningkatan aktivitas guru dalam proses pembelajaran sebagaimana terlihat pada tabel berikut.

Tabel 4.13.

Tabel Peningkatan Aktivitas Guru.

\begin{tabular}{ccc}
\hline Keterangan & Siklus I & Siklus II \\
\hline Aktivitas Guru & 3,38 & 3,92 \\
\hline Kategori & Baik & Sangat baik \\
\hline
\end{tabular}

Sumber: Hasil Penelitian (2020).

Berdasarkan hasil pengamatan di atas, terlihat peningkatan aktivitas guru pada materi gerak benda melalui penerapan model tipe Student Teams Achievement Division (STAD) dari siklus I hingga siklus II, pada siklus I aktivitas guru dikategorikan baik $(3,38)$, Pada siklus ke II aktivitas guru dikategorikan menjadi sangat baik $(3,92)$. Berdasarkan nilai rata-rata kelas maupun persentase klasikal, tampak bahwa pelaksanaan pembelajaran dengan menerapkan model pembelajaran tipe STAD dapat meningkatkan hasil belajar siswa secara signifikan.

Aktivitas siswa dalam proses pembelajaran perawatan sasis sepeda motor materi sistem rem dengan menggunakan model tipe Student Teams Achievement Division (STAD) pada penelitian dilihat berdasarkan hasil observasi yang telah dilakukan oleh pengamat. Peningkatan tersebut dapat dilihat pada tabel berikut:

Tabel 4.14

Peningkatan Hasil Aktivitas Siswa.

\begin{tabular}{lll}
\hline Keterangan & Siklus I & Siklus II \\
\hline
\end{tabular}

$\overline{\text { Al-Madãris, Volume l (1), } 2020}$ 


\begin{tabular}{ccc}
\hline Aktivitas siswa & 3,23 & 3,84 \\
\hline Kategori & Baik & Sangat baik \\
\hline
\end{tabular}

Sumber: Hasil Penelitian (2020).

Berdasarkan hasil pengamatan di atas, terlihat peningkatan aktivitas siswa dalam pembelajaran perawatan sasis sepeda motor pada materi sistem rem dengan menggunakan model tipe Student Teams Achievement Division (STAD) dari siklus I hingga siklus II, pada siklus I aktivitas siswa dikategorikan baik $(3,30)$, selanjutnya pada siklus II aktivitas siswa menjadi sangat baik dengan skor $(3,92)$. Pada saat guru melakukan pembelajaran, aktivitas guru dan siswa di observasi oleh pengamat.

Adapun perolehan nilai yang didapatkan dari tes siswa sesudah mengikuti proses belajar mengajar pada siklus I dan siklus II memperoleh peningkatan melalui perolehan rata-rata 56,45 di siklus I mengalami peningkatan 8,33 kemudian perolehan rata-rata 63,96 di siklus II mengalami peningkatan 10,63. Adapun perolehan persentase peningkata hasil belajar siswa dari siklus I ke siklus II sebesar 4,17\% pada kriteria baik sekali, 25,0\% pada kriteria baik dan $8,40 \%$ pada kriteria cukup.

Respon siswa dilakukan dengan mengedarkan angket, maka hasil penelitian dan pengolahan data melalui angket diperoleh gambaran mengenai respon siswa, adapun perolehan nilai tertinggi 94,21\% yaitu terdapat pada tanggapan siswa merasa terbantu dengan adanya model pembelajaran kooperatif tipe STAD dalam mengatasi kesulitan belajar. Adapun persentase nilai terendah 39,93\% yaitu terdapat pada tanggapan siswa agar model pembelajaran kooperatif tipe STAD digunakan dalam pembelajaran materi gerak benda selanjutnya dan mata pelajaran lain.

\section{F. Kesimpulan}

Hasil belajar siswa dengan menggunakan model pembelajaran kooperatif tipe STAD mengalami peningkatan melalui perolehan rata- rata 56,45 di siklus I mengalami peningkatan 8,33 kemudian 63,96 di siklus II. Aktivitas guru dan siswa terjadinya peningkatan dalam proses belajar mengajar dengan menggunakan model pembelajaran kooperatif tipe Student Teams Achievement Division (STAD), pada mata pelajaran IPA pada materi gerak benda siswa kelas VIII MTsN 3 Aceh Utara, ditunjukkan baik pada siklus 1 aktivitas guru dengan katagori baik. Terjadi peningkatan pada siklus 2, yaitu dangan kategori baik. Selanjutnya aktivitas siswa pada siklus 1, dengan kategori baik. dan terjadi peningkatan pada siklus 2 dengan kategori sangat baik. Respon siswa setelah diterapkannya model pembelajaran kooperatif tipe Student Teams Achievement Division (STAD) menunjukkan respon yang positif dan hendaknya model ini dapat diterapkan pada pembelajaran untuk konsep selanjutnya.

\section{BIBLIOGRAFI}

Agus suprijono. 2010. Cooperative Learning. Yogyakarta. Pustaka Media. Arikunto, Suharsimi, 2009. Penelitian Tindakan Kelas. Jakarta: Rineka Cipta. Aqib, Zainal. 2011. Penelitian Tindakan Kelas. Bandung: Yrama Media. Darsono M. 2000.Belajar dan Pembelajaran. Semarang: IKIP semarang Press. 
Depdiknas. 2004. Pendekatan Konstekstual. Jakarta: Direktorat Pendidikan Lanjutan Pertama. Direktorat Jenderal Pendidikan Dasar dan Menengah.

Departemen Pendidikan Nasional. 2006. Peraturan Menteri Pendidikan Nasional Republik Indonesia No.22 tahun 2006 tentang Standar Isi. Jakarta: Depdiknas.

Djamarah. 2006. Strategi Belajar Mengajar. Jakarta: Rineka Cipta.

Dimyati dan Mudjiono. 2002. Belajar dan Pembelajaran. Jakarta: Rineka Cipta dan Depdikbud.

Freddy Rangkuti. 2009. Strategi Promosi Yang Kreatif. Jakarta: Gramedia Pustaka Utama.

H.B. Sutopo. 2006. Metodologi Penelitian Kualitatif: Dasar teori dan Terapannya dalam Penelitian. Surakarta: Universitas. Sebelas Maret.

Hendrik Arung Lamba. 2006. Pengaruh Pembelajaran Kooperatif Model STAD dan Gaya Kognitif Terhadap Hasil Belajar Fisika Siswa SMA. Jurnal Ilmu Pendidikan. Jilid 13. No.2.

Ni Made Sunilawati, Nyoman Dantes dan I made Candiasa. 2003. Pengaruh Model Pembelajaran Kooperatif Tipe STAD Terhadap Hasil Belajar Matematika Ditinjau Dari Kemampuan Numerik Siswa Kelas IV SD. Jurnal Program Pascasarjana Universitas Pendidikan Ganesa. Vol 3.

U. Nugroho, Hartono dan Edi. 2009. Penerapan Pembelajaran Kooperatif Tipe Stad Berorientasi Keterampilan Proses. Jurnal Pendidikan Fisika Indonesia. Vol.5. ISSN: 1693-1246

Sudjana N. 2002. Media Pengajaran. Bandung: Sinar Baru Aglgesindo

Sardiman. 2011. Interaksi dan Motivasi Belajar Mengajar. Jakarta: Rajawali Press.

Syah, Muhibbin. 2012. Psikologi Belajar. Jakarta : Raja Grafindo Persada. 